\title{
Novi trendi $v$ razvoju in organiziranosti sodobnih organizacij
}

\author{
UDK 061.5 (658) \\ Štefan Ivanko \\ Fakulteta za upravo \\ stefan.ivanko@cubus-i.si
}

\section{IZVLEČEK}

Prispevek osvetljuje težnje $\mathbf{v}$ razvoju in organiziranosti sodobnih organizacij, ki se kažejo zlasti v odvajanju proizvodnje od virov surovin in zaposlovanja, globalizaciji poslovanja in spremembi ciljev ter načinov delovanja. Strnjeno so prikazani viri preoblikovanja in uspešnosti poslovanja sodobnih organizacij, kot so informacije, komunikacije, znanje in upravljanje, ki postajajo temeljni dejavniki uspešnosti poslovanja sodobnih organizacij. Spremenjeni dejavniki uspešnosti poslovanja terjajo tudi spremembe v organiziranosti sodobnih organizacij. Oblike sodobne organiziranosti so predvsem oblike mrežne in virtualne organiziranosti ter skupnosti e - poslovanja. Posebno mesto v mrežni organiziranosti pa zavzema projektna organiziranost, ki postaja pomembna sestavina menedžmenta vsake sodobne organizacije.

Ključne besede: globalizacija, informacija, komunikacija, znanje, upravljanje, organizacija, projekt.

\section{Težnje v razvoju sodobnih organizacij}

Informacije so temeljni vir sodobnega delovanja organizacij. Informacije so pri svoji izmenjavi zelo fleksibilne. Niso omejeni s carinami, mejami ali administrativnimi ovirami. Informacije zaradi svojih lastnosti omogočajo razširjanje področij delovanja sodobne organizacije.

Informacije se razlikujejo od vseh dosedanjih virov, na katerih je temeljil razvoj podjetij. Značilna je njihova dostopnost vsem tistim, ki jih znajo uporabljati. Za to pa je potrebno predvsem znanje, ki postaja edini resnični kapital sodobne organizacije.

Znanje, potrebno za ustvarjalno in organizirano odzivanje na informacije, postaja odločilna prvina v konkurenčnem boju, a menedžment kot nosilec znanja in organizator posameznega specializiranega znanja, glavni podjetnik v podjetniški organizaciji. Glede na navedeno je možno pričakovati, da bodo smeri razvoja sodobne organizacije $\vee$ (Zekić, 1997, str. 28):

- odvajanju proizvodnje od surovin in zaposlovanja,

- globalizaciji poslovanja,

- spremembi cilja in načina delovanja. 


\section{Štefan Ivanko \\ Novi trendi v razvoju in organiziranosti sodobnih organizacij}

Proizvodnja dobrin se vse bolj oddaljuje od vira surovin in človeškega dela. Svetovni gospodarski trendi se danes gibljejo $v$ smeri reindustrializacije na podlagi visoke tehnologije in integracije svetovnega gospodarstva. Dosedanja rast proizvodnje je temeljila predvsem na izrabi naravnih virov. Naravne surovine, ki postajajo grlo visoke informacijske tehnologije, se postopno zamenjujejo z novo proizvedenimi materiali, ki so rezultat preoblikovanja surovin s pomočjo kemijskih postopkov in tehnik odvajanja, kombiniranja in oblikovanja. Biokemija, na primer, ki se smatra za tehnologijo bodočnosti, pomeni uporabo biologije $v$ tehnološkem procesu proizvodnje, na način, ki ni znan $v$ naravi, privede do tega, da zemljiška renta ni več proizvod zemlje, temveč znanja, ki je ustvarjeno v laboratoriju.

Dejavniki razvoja se tako spreminjajo od materialnih $k$ nematerialnim, točneje $k$ znanju. Za sedanjo fazo razvoja tehnologije, gospodarstva kot tudi same organizacije je značilno, da se konkurenčna prednost dosega s proizvedenimi, a ne več toliko z naravnimi viri.

Sodobne tehnologije s svojimi ekonomskimi učinki so močno spremenile potrebe po človeškem delu in delovni sili. Avtomatizirani in robotizirani proizvodni procesi odstranjajo človeka kot izvajalca iz proizvodnih procesov. $V$ takšnih procesih ni več potrebna človeška fizična sila. Človek se $v$ takšnih procesih vključuje predvsem kot kontrolor oz. upravljavec teh procesov. Za potrditev navedenega nazorno priča dejstvo, da se vrednost čipa, ki največ prispeva k neposrednemu razvoju informacijske tehnologije, sestoji od okoli $70 \%$ tehničnega znanja, okoli $12 \%$ direktnega dela in samo okoli 3\% materiala (Zekić, 2000, str. 37). Dejstvo je, da informacije, komunikacije in znanje ter upravljanje kot sposobnost, da se ustvarjalno odziva na novo informacijo, postajajo najvažnejši dejavniki razvoja sodobne organizacije in da zemlja, delo in kapital, na katerih je temeljila dosedanja proizvodnja in razvoj podjetja, postopno postajajo sekundarni.

Znanstveno tehnološki razvoj že sedaj omogoča informatizacijo proizvodnih in menjalnih procesov, pri čemer postaja informacija odločilni dejavnik sodobnega gospodarjenja. Z avtomatizacjo, računalništvom in robotizacijo proizvodnih procesov nastajajo nove proizvodne sile, ki presegajo tovarniške in državne meje. Te sile terjajo globalna prostranstva razvitih komunikacij in vsestransko izprepletene odnose, ki prisiljujejo razvite dežele, da tesneje povezujejo svoja gospodarstva in da ustvarjajo medsebojno odvisne integracije ekonomskih kompleksov, ki prispevajo k nadaljnjemu razvoju svetovnega gospodarstva. Ustvarjajo se transnacionalna gospodarstva, ki prevladujejo $\mathrm{v}$ gospodarstvih nacionalnih držav.

Za transnacionalno gospodarstvo so bolj značilni pretoki denarja kot pa blaga in storitev. $\vee$ transnacionalnem gospodarstvu postajajo tradicionalni dejavniki proizvodnje, kot so zemlja in delovna sila, vse bolj sekundarni. Tudi denar postaja vse bolj transnacionalen in ga je možno nabaviti povsod, zato ni več najpomembnejši dejavnik proizvodnje.

$\checkmark$ sodobnem podjetju je management odločilen dejavnik, na katerem temelji konkurenčna prednost podjetja. Pri tem zavzema upravljanje z logistiko oz. prostorsko in časovno preoblikovanje proizvodnih dejavnikov in njihovih izdelkov posebno mesto ter postaja strateška določnica sodobne organizacije. 
Sodobna organizacija mora delovati in biti organizirana kot globalna organizacija, ki mora biti vključeno $v$ svetovni gospodarski sistem. Za globalna tržišča je značilna velika diverzifikacija proizvodnje, ker potrošniki vse več zahtevajo različice enakih izdelkov. Raziskave in razvoj postajajo vse bolj pomembne pri ustvarjanju izdelkov z veliko dodano vrednostjo, z vse večjim deležem znanja in tehnologije. Izdelki sodobnih podjetij se morajo plasirati na vse večjih trgih, da se tako lahko povrnejo investicije v raziskave in razvoj. Temu prispeva tudi sklepanje raznih zavezništev, ki zmanjšujejo tveganja in pospešujejo plasman.

$\checkmark$ spremenjenih razmerah dela in poslovanja postajajo transnacionalne korporacije organizacije bodočnosti, ki jih spremljata tudi procesa globalizacije in decentralizacije. Moč sodobne organizacije ni v njeni velikosti, ker so tudi majhne organizacije lahko transnacionalne. Njihova moč je $\vee$ tem, da preko raznih oblik sodelovanja in povezovanja, poskušajo obvladovati vse več tujega kapitala. Pri tem ne gre za lastništvo kapitala, temveč za znanje, to je upravljanje in podjetništvo.

$\checkmark$ sodobni organizaciji so spremenjeni tudi cilji in načini njenega delovanja. Znanje postaja kapital razvitega gospodarstva. Izobraženi zaposleni določajo družbene vrednote in norme. Iz gospodarskega življenja je istisnjen "kapitalist", ki je zamenjan z velikim številom zaposlenih in velim številom prebivalstva z raznimi oblikami organiziranega kapitala. Kapital se pojavlja kot družbeni vir, ki je težko opredeljiv, in njega ne poseduje le kapitalist, temveč velika večina prebivalcev. Ko kapital postane družbeni vir, njegov cilj in cilj organizacije, ne more biti več le maksimalizacija dobička. Simbioza kapitala, dela in samega podjetja z željami in interesi celotnega prebivalstva terja več ciljev, od katerih je temeljni kvaliteta življenja (Zekić, 2000, str. 39).

$\checkmark$ sodobnih družbah so zaposleni praviloma solastniki kapitala in tudi uporabniki izdelkov ali storitev organizacije, zato zahtevajo od organizacije, da zadovolji njihove naravne in družbene cilje ter interese. Zaščita narave in zdravo življenje prebivalcev je eden od takšnih ciljev, ki terja visoko mesto $v$ hierarhiji sodobne organizacije.

Cilj sodobne organizacije je maksimalizacija njene sposobnosti, da proizvaja obilje in bogastvo $v$ polnem pomenu teh pojmov, kar terja večstranskost ciljev, a ne samo maksimalizacijo dobička (Zekić, 2000, str. 39).

Ko postane kapital družbeni vir, postane dobičkonosnost družbena odgovornost (Drucker, 1992, str. 4). Organizacije, ki ne ustvarjajo ta cilj oz., ki ne zaslužijo dovolj za stroške kapitala, v resnici kradejo družbi, ker družbi ne vračajo sredstev, ki jim jih je dala na razpolago, da jih koristno uporabijo za zagotavljanje temeljnih ciljev. Dobiček postaja nujno sredstvo za ustvarjanje temeljnega cilja, to je proizvodnja blaginje in bogastva tako za lastnike kot za kupce in tudi za celotno družbo.

Organiziranost sodobnih organizacij postaja začasna in nestabilna. Slabša se tudi navezanost ljudi z organizacijo, čeprav se odnos organizacije do zaposlenih humanizira; humanizira se tudi odnos organizacije do njenega gospodarskega in družbenega okolja.

$\checkmark$ sodobni organizaciji, ki je tudi sposobna samoorganiziranja, se povečuje sposobnost za reševanje zapletenih problemov. $V$ sodobni organizaciji so tudi ustvarjeni pogoji, da si človek organizacija, organizacija in organizacija in organizacija ter družbene institucije več ne nasprotujejo druga drugi, temveč da se skupno usmerijo na reševanje skupnih problemov. 
Štefan Ivanko

Novi trendi v razvoju in organiziranosti sodobnih organizacij

\section{Viri preoblikovanja in uspešnosti poslovanja sodobne organizacije}

Spremenjeni dejavniki, ki odločilno vplivajo na uspešnost organizacije so posledica tehnološkega in celotnega družbenega razvoja. Temeljni dejavniki uspešnosti sodobne organizacije so in bodo zlasti (Zekić, 2000, str. 40):

- informacije,

- komunikacije,

- znanje in

- upravljanje.

\subsection{Informacije kot vir prestrukturiranja sodobne organizacije}

Informacije so viri za prestrukturiranje sodobnih organizacij. Informacije postajajo najpomembnejša substanca sodobnih izdelkov ali storitev in so osnovni dejavnik sodobne organizacije. Informacijo moremo obravnavati kot negacijo entropije, kot mero reda, mero organiziranosti in kot konstitutivno prvino sodobne organizacije (Uzelac, 1994, str. 83). Razvoj sodobne organizacije temelji na informacijah in njihovi izmenjavi z okoljem. Dejstvo je, da po začetku osemdesetih let, zaposlitev $\vee$ klasični proizvodnji nazaduje in da se glavnina zaposlitve prenaša na informacijski sektor.

Edini omejitveni dejavnik pri uporabi informacij je človeška sposobnost oz. znanje. Informacija odločilno vpliva na vsak izdelek ali storitev. Informacija je temelj večji ali manjši konkurenčni sposobnosti vsake organizacije. Informacija je enako donosna v veliki ali majhni organizaciji (Sundać, 1992, str. 21). Informacije imajo odločilen vpliv na prestrukturiranje sodobne organizacije. Hitra in tvorna izmenjava informacij znotraj organizacije in tudi z njenim okoljem, kot pogoj uspešnega delovanja organizacije, terja tudi zamenjavo vertikalne organiziranosti $\vee$ vodoravno.

Tako kot se sodobna organizacija vse bolj usmerja h kupcu in porabniku, tako tudi narašča pomen informacij kot dejavnika njene uspešnosti.

Z informacijo sta povezana dva temeljna dejavnika, tj. prostor in čas. Čas vstopa organizacije na neko tržišče do pojava konkurence je velika njena tržna prednost, ki se odraža v dobičku. Hitrost gibanja proizvodnih tvorcev in izdelkov kaže na to, da se prostor kot ekonomska sestavine vse hitreje in lažje obvladuje, medtem ko se čas v komunikacijskem in informacijskem pomenu vse bolj skrajšuje.

\subsection{Komunikacija kot način delovanja sodobne organizacije}

Informacije so temeljni vir uspešnosti delovanja sodobne organizacije. Svoj namen in cilje dosegajo le z ustrezno izmenjavo med pošiljatelji in prejemniki informacij. Izmenjava informacij se opravlja $v$ procesih komuniciranja. Informacijske komunikacije povezujejo informacijske procese ustvarjanja, prenosa, uporabe in shranjevanja informacij. 
$\checkmark$ sodobnem podjetju je komuniciranje pogoj za obstoj in delovanje organizacije $\vee$ konkurenčni borbi na tržišču. $V$ sodobnem tržnem gospodarstvu se kupec obravnava predvsem kot vir informacij in šele nato kot uporabnik oz. potrošnik.

Pogoj za uspešno gospodarjenje z informacijami je izgradnja ustreznega informacijskega sistema, ki je sestavni del vsakega upravljavskega in ciljno usmerjenega poslovnega sistema. Cilj informacijskega sistema je nenehno oskrbovanje z informacijami vse ravni upravljanja in odločanja $v$ danem tehnološkem in organizacijskem sistemu. Uspešno poslovanje organizacije terja prenos informacij na vse ravni delovnih mest v organizaciji. Šele s prenosom informacij na mesta izvršitve, postanejo informacije vir poslovanja. Komunikacijski sistem tako predstavlja svojevrstno infrastrukturo, ki omogoča hitro in večsmerno izmenjavo informacij, v kateri je vsak udeleženec sočasno vir informacij in tudi njihov prejemnik (Zekić, 2000, str. 42). To omogoča, da zaposleni postanejo resnično sodelavci, kar tudi omogoča ustvarjanje znanja kot temeljnega ustvarjalca vrednosti v sodobni organizaciji.

\subsection{Znanje kot ustvarjalec vrednosti}

Uporaba informacij kot temeljnega vira uspešnosti delovanja sodobne organizacije predpostavlja ustrezno znanje za razumevanje in uporabo informacij. Znanje je posrednik in transformator $v$ pretvarjanju informacij $\vee$ nove oblike in nove vsebine, $v$ novo znanje, nove tehnologije in nove izdelke. Spremembe $v$ okolju, spremembe $\vee$ tehnologiji, nastajanje novih možnosti in potreb terjajo tudi spremembe nosilca vsega tega, to je človeka. Klasični proizvodni delavec se vse bolj spreminja in postaja informacijski delavec. Informacije in zanje so njegovi predmeti in sredstva dela. Ustvarjalno človeško delo oz. znanje postaja ustvarjalec vrednosti izdelkov in tudi same organizacije (Zekić, 2000, str. 42). Za optimiranje poslovnih rezultatov, je potrebno upravljanje z znanjem in same organizacije postajajo tudi proizvajalci znanja.

$\checkmark$ razmerah negotovosti in turbulentnega okolja znanje postaja edini trajni vir sposobnosti organizacije za njen obstoj na tržišču. Pri tem seveda ne gre za vsakršno znanje, temveč za znanje, ki omogoča uporabo sodobne tehnike in tehnologije. Za trajen obstoj podjetja $v$ sodobnem okolju je potrebno nenehno inoviranje vseh aktivnosti. Novo znanje ne nastaja z enostavno obdelavo obstoječih informacij. Glavne spodbude za ustvarjanje novega znanja prihajajo od osebnega angažiranja vseh zaposlenih, njihovih spretnosti in motiviranosti, da se poistovetijo z organizacijo. Da bi se udeležba doseženega znanja zaposlenih lahko aktivirala in spremenila $v$ nove tehnologije, nove izdelke, je potrebna prenova celotne organizacije zlasti $\vee$ obnašanju zaposlenih. $\vee$ resnici gre za oblikovanje učeče se organizacije. $V$ tem tudi odseva podjetniška vloga in odgovornost menedžmenta.

\subsection{Upravljanje kot ciljno usmerjanje virov in procesov}

V splošnem je upravljanje usmerjanje in vodenje organizacije ali procesov proti želenim ciljem oz. rezultatom. Za upravljanje organizacije ali procesov in usmerjanja na 


\section{Štefan Ivanko}

Novi trendi v razvoju in organiziranosti sodobnih organizacij

obnašanje zaposlenih, ki vodi k uresničevanju ciljev, so potrebne informacije, ki morajo omogočiti odpravo motenj in doseganje želenih ciljev delovanja organizacije ali procesov.

Sodobna organizacija je odprt sociotehnični sistem. Pri sprejemanju vhodnih sestavin je organizacija izpostavljena delovanju okolja. Za normalno delovanje in svoj obstoj se mora prilagajati delovanju vplivov iz okolja. Povratno delovanje oz. informacijsko zrcaljenje med rezultati in podjetniškimi aktivnostmi mora omogočiti korekcije nepredvidenih vplivov iz okolja. Zunanji in notranji vplivi ter cilji organizacije vplivajo na aktivnosti za izrabo virov in oblikovanje organiziranosti sodobne organizacije. To omogoča odvijanje poslovnih procesov in doseganje želenih rezultatov.

Stalne spremembe vplivov iz okolja terjajo dinamično obnašanje organizacije do svojega okolja. V takšnih razmerah je upravljanje lahko učinkovito le, če je zasnovano na prenosljivosti informacij in kakovostnem komunikacijskem sistemu oz. če je zasnovano na znanju.

Drucker meni, da je upravljanje v resnici "uporabno znanje", a nova tehnologija ni nič drugega kot podjetniško upravljanje oz. tehnologija sistemskega namenskega vodenja podjetništva (Drucker, 1992, str. 20). Meni tudi, da je menedžment ta nova tehnologija, ki uporablja razpoložljive vire in ki pretvarja klasično organizacijo $v$ sodobno podjetniško organizacijo. $V$ takšni organizaciji zaposleni, ki razpolagajo z informacijami, komunikacijami in znanjem, postajajo podjetniki, ki jih usmerja menedžment $k$ doseganju skupnih ciljev. Menedžment je voditelj in usklajevalec njihovih podjetniških aktivnosti in agens pretvorbe te ustvarjalnosti v stalni proces ustvarjalnega ustvarjanja novih vrednosti, da bi se tako ustvarili njihovi cilji, cilji organizacije in celotne družbe.

Klasična industrijska organizacija je bila proizvodno usmerjena. Delovala je v stabilnem okolju. Organizacijsko je bila oblikovana za doseganje maksimalne učinkovitosti proizvodnih virov $v$ procesu proizvodnje določenih izdelkov ali storitev. Vse to je terjalo togo hierarhično organiziranost in natančno opravljanje dodeljenih nalog od menedžerjev, da bi se tako zagotovila uspešnost poslovanja.

Pospešeni tehnološki razvoj in stalne spremembe okolja prisiljujejo menedžment sodobne postindustrijske tržno usmerjene organizacije, da uspešnost poslovanja temelji na dinamičnih sestavinah organizacije, to je človeških potencialih, ki morajo biti motivirani, da s svojim znanjem in ustvarjalnostjo prispevajo k dinamični optimizaciji poslovanja organizacije, ki se $v$ takšnih razmerah ustvarja predvsem z logističnim prilagajanjem spremembam v okolju (Zekić, 2000, str. 45).

\section{Vloga menedžmenta v sodobni organizaciji}

Temeljni dejavnik uspešnosti poslovanja sodobne organizacije je menedžment. Menedžment obsega proces planiranja ciljev, organiziranja virov in aktivnosti, upravljanja s človeškimi potenciali in materialnimi viri, potrebnimi za delovanje in učinkovito doseganje ciljev $\vee$ spremenjenem okolju. $\vee$ razmerah sodobne podjetniške ekonomije, ko kapitalist ni več edini lastnik kapitala, ker imajo kapital široki sloji prebivalstva, se terja združevanje kapitala, ker njegovo oplojevanje terja organizirano proizvodnjo večjega obsega. 
Sodobne korporacije z veliko družbeno odgovornostjo in ustrezno menedžersko strukturo, lahko privabijo velike vire zasebnega kapitala, proizvajajo širok asortiment izdekov, združujejo tveganja in koristijo ekonomijo velikih raziskovalnih enot in menedžerskega znanja (Samuelson \& Nordhaus, str. 106). V takšnih razmerah je dobiček, čeprav ni več edini cilj delovanja sodobne organizacije, še vedno pomemben, ki zagotavlja razvoj oz. zagotavlja neprekinjeno odvijanje reprodukcijskih ciklusov. Kapital se torej vlaga zaradi doseganja dobička, ki je pogoj za razvoj sodobne organizacije.

Sodoben menedžer prevzema podjetniško vlogo od lastnika kapitala in postaja odločujoč dejavnik uspešnosti sodobne organizacije. Poleg tradicionalnih nalog menedžmenta menedžer tu organizira proizvodnjo, uvaja nove ideje, izdelke in postopke, sprejema poslovne odločitve in je odgovoren za uspeh ali propad organizacije.

Sodobna organizacija se mora prilagajati spremembam poslovnega okolja. Poslovno okolje sodobne organizacije, ki se globalizira, označujejo nepredvidljivi poslovni dogodki in hitrejše spremembe, kot pa je sposobnost prilagajanja organizacije tem spremembam. To dejstvo terja od organizacije spremenjeno obnašanje, ki je bilo usmerjeno $v$ pretekle izkušnje organizacije $v$ inovativno podjetniško obnašanje, ki mora biti usmerjeno v novosti, nekontinuiranost in večja tveganja. Takšna transformacija terja od organizacije, da poleg razvijanja sodobne proizvodne in informacijske tehnologije, razvijajo tudi sodobne upravljalne tehnologije. Upravljanje sodobne organizacije ne more biti več umetnost, ki se lahko obvladuje z malo naravnega talenta in zadostnimi izkušnjami, temveč postaja vse bolj znanost. Informacije in znanje so instrumenti sodobnega menedžmenta; pripravljenost za prevzemanje podjetniškega tveganja pa postaja pogoj za obstanek organizacije, s katero upravlja.

$\checkmark$ sodobnem nestabilnem okolju mora upravljanje organizacije temeljiti na znanju, biti mora aktivno in prilagodljivo novim razmeram. Sodobni menedžment mora aktivno iskati možnosti in priložnosti, premišljeno tvegati, uvajati spremembe in izboljšave, naslanjati se na ljudi in ne na stvari, da bi zagotavljal uspešnost poslovanja organizacije. Menedžerji tako postajajo vodje, ki morajo misliti in delovati kot podjetniki. Sposobnost organizacijskega prilagajanja spremenjenim zahtevam, ciljem in nalogam poslovanja, opredeljuje podjetniško vlogo sodobnega menedžmenta.

Zaposleni $\vee$ organizaciji predstavljajo dinamično substanco organizacije. Upravljanje s človeškimi potenciali in njihovo vključevanje $v$ upravljanje organizacije postaja najvažnejša funkcija menedžmenta in strateška usmeritev sodobne organizacije. Hitro spreminjajoče okolje prisiljuje sodobni menedžment, da se mora odločiti za gibko prilagajanje in prilagodljivo obnašanje $v$ svojem poslovnem in celotnem družbenem okolju.

Z razvojem tehnologije oz. s pojavom visoko sofisticiranih tehnologij se dogaja paradoksalni pojav, da je uspešnost organizacije vse bolj odvisna od ljudi, njihovega znanja, ustvarjalnosti in podjetniškega obnašanja. Barlett meni, da morajo menedžerji zato spremeniti svoj sistem “organizacijskega človeka" s sistemom "individualizirana korporacija", ki temelji na ciljnem vodenju, temelječem na procesih in ljudeh (Zekić, 2000, str. 46). 


\section{Štefan Ivanko}

Novi trendi v razvoju in organiziranosti sodobnih organizacij

Za sodobne razmere je značilno vse hitrejše poenotenje tehnoloških osnov proizvodnje, občutno skrajševanje življenskega cikla izdelkov, vse bolj izražena raznovrstnost potreb in želja vse bolj zahtevnih kupcev, kar terja od menedžmenta, da opusti sistem upravljanja, ki zagotavlja kontrolo in usklajenost, ker to omejuje ustvarjalnost in iniciativnost zaposlenih. $V$ novih razmerah so motivirani zaposleni osnovni kapital organizacije, izboljšanje komunikacij in medsebojno sodelovanje na vseh področjih je osnovni pogoj za doseganje uspešnosti poslovanja sodobne organizacije.

$\checkmark$ sodobnem svetu postajajo zaposleni vse bolj solastniki organizacij in hkrati tudi uporabniki njihovih izdelkov ali storitev. Zaposleni so tudi ljudje, ki sočasno trpijo posledice podjetniškega delovanja, kar vpliva na to, da poslanstvo sodobne organizacije ne more biti več izključno ekonomsko in da se organizacije morajo vse bolj obvladovati na načine, ki jih uporablja celotna družba.

Uspešnost sodobne organizacije se ne meri samo z merili ekonomske učinkovitosti pri doseganju ciljev organizacije. Poleg ostvarjenega dobička, porasta prodaje idr. postajajo pomembni kazalnik kakovostnega položaja na trgu, kot so poslovni ugled in pozitivni image, število stalnih kupcev, poslovni partnerji idr. Uspeh poslovanja je prvenstveno odvisen od strokovnosti in sposobnosti menedžmenta in njegove motiviranosti za učinkovito sodelovanje z vsemi udeleženci svoje organizacije.

Konkurenčna prednost sodobne organizacije se vse težje ustvarja $\vee$ proizvodnji. Težišče aktivnosti za povečanje uspešnosti sodobne organizacije se prenaša na prostorsko - časovno preoblikovanje dobrin oz. na področje logistike, ki jo je težko avtomatizirati, ker je njena učinkovitost posledica človeške ustvarjalnosti, organizacijskih sposobnosti in inovativnosti (Zekić, 2000, str. 47).

Skladno z razvojem gospodarstva se dejavniki njegovega razvoja pomikajo od materialnih k nematerialnim oz. od naravnega in proizvedenega kapitala k človeškemu kapitalu to je znanju. $\vee 29$ razvitih državah je človeški kapital kot dejavnik bogastva udeležen že s 67 odst. (Zekić, 2000, str. 47.

\section{Organiziranost sodobne organizacije}

Nova ekonomija nudi tudi nove možnosti organiziranja organizacij. Internet in drugi spremljajoči proizvodi informacijskih tehnologij prinaša možnosti drugačnega organiziranja poslovanja. Osnovna njegova značilnost je, da poslovanje ni več zaprto $\vee$ okvirje obstoječih organizacij, temveč se povezuje $z$ drugimi organizacijami $\vee$ različne oblike poslovnih mrež. Omejitveni dejavniki pri tem so le znanje, inovativnost in sposobnost izpeljave novih poslovnih idej $\vee$ prakso. $\vee$ novi ekonomiji postajajo mreže glavna oblika organiziranosti poslovanja. Z različnimi mrežami so med seboj povezani ljudje, predmeti in organizacije, ki tako postajajo vedno bolj povezana celota. Organiziranost organizacij nove ekonomije ne omejujejo več razpoložljivi viri organizacije, kot je to bilo značilno $v$ času industrijske dobe, ki so pri svojem delovanju bile bolj ali manj zaprte $\vee$ okvire svojih proizvodenj. Organizacije nove ekonomije iščejo nove načine in oblike, kako najbolje uporabiti tudi zunanje razpoložljive vire, ki so jim dosegljivi prek različnih mrežnih povezav. Omejitveni dejavnik torej niso več lastni viri, 
temveč znanje, inovativnost, ideje, sposobnost inovativnih rešitev. Novodobne organizacije koristijo sodobno informacijsko tehnologijo in telekomunikacije za vzdrževanje in razvoj svojih konkurenčnih prednosti.

Novo poslovno okolje, ki je nastalo s pojavom tehnologije spletnih strani, omogoča vrsto novih oblik poslovnega delovanja in povezovanja.

Uspešnost sodobnih organizacij terja tesnejše poslovno in razvojno povezovanje s svojimi dobavitelji, kupci in drugimi partnerji in skušajo oblikovati optimalne poslovne verige dodajanja nove vrednosti. Takšnih poslovnih povezav si ne moremo zamisliti brez elektronskega poslovanja (e-poslovanje). Nastajajo "skupnosti e-poslovanja (SEP)". Tapscott (Semolič, 2001, str. 17) opredeljuje SEP kot mrežo dobaviteljev, distributerjev, prodajalcev, kupcev in drugih, ki uporabljajo internet kot podlago za sodelovanje in konkuriranje. SEP pomeni $v$ novi ekonomiji nov konkurenčni prostor, ki omogoča uveljavljanje zakonov nove ekonomije. SEP postavlja organizacijam tudi nova pravila poslovanja in konkurenčnosti, spreminja kriterije vrednosti in mobilizira vire in ljudi v nove inovativne oblike sodelovanja in poslovanja. Sodelovanje organizaciij v SEP terja drugačne poslovne odnose in obnašanje. Prinaša jim dolgoročne ugodne razmere poslovanja za vse sodelujoče $\vee$ SEP. Pogoj za to je potreba po koreniti spremembi načina razmišljanja in odnosov do poslovnih partnerjev.

Organiziranost organizacij, gledano razvojno, se je spreminjala v skladu s spreminjanjem tehnologije zlasti tekomunikacijske in informacijske ter sprememb $v$ družbenoekonomskih odnosih danih družb. Nastanek in razvoj oblik organiziranosti organizacij je možno obravnavati z različnih vidikov. Tapscott npr. razvršča razvoj organiziranosti podjetij in drugih organizacij $\vee$ tri temeljne značilne skupine oziroma faze (Tapscott, 1988 in Semolič, 2001, str. 18):

- organiziranost podjetij in drugih organizacij industrijske dobe,

- virtualna organizacija in

- skupnost e-poslovanja (SEP).

Prvo skupino oziroma fazo zajemajo podjetja in organizacije industrijske dobe, ki so organizirana in delujejo po klasičnih organizacijskih načelih. Osnovni tipi klasičnih organizacijskih oblik so funkcijska, divizijska, matrična in delno tudi projektna organiziranost (Ivanko, 2000, str. 29 - 62). Glavne značilnosti te faze oziroma tega razvojnega obdobja so stabilne tehnologije in poslovni ter proizvodni procesi. Organiziranost poslovanja je bolj ali manj hierarhična in primerna za serijsko in množično proizvodnjo. Ponudniki blaga in storitev dominirajo. Kupci in uporabniki izdelkov ali storitev imajo malo možnosti za zadovoljevanje svojih specifičnih potreb, želja in načrtovanja v okviru proizvodnih ciklov.

Drugo razvojno fazo zavzemajo bolj prilagodljive oblike organiziranosti. Takšne oblike organiziranosti so predvsem prve oblike klasične mrežne organiziranosti in procesne organiziranosti podjetij in drugih organizacij. Značilnosti teh oblik organiziranosti so, da povezujejo organizacije, dobavitelje, distributerje, prodajalce in celo kupce $v$ skupno mrežo. Elektronska izmenjava podatkov (EDI - Electronic Data Interchange) in računalniška mreža (client/server) je temeljna tehnologija povezovanja organizacij (Semolič, 2001, str.18). 


\section{Štefan Ivanko \\ Novi trendi v razvoju in organiziranosti sodobnih organizacij}

Klasična dinamična mreža je že ustaljena oblika poslovne organiziranosti. Značilnost te strukture je, da je $v$ resnici nevidna. Bistvo te strukture so povezave organizacij, ki med seboj sodelujejo pri proizvodnji kompleksnega izdelka, storitve ali določenega projekta preko računalnikov. $V$ dinamično strukturo so povezani vsi udeleženci pri proizvodnji kompleksnega izdelka ali pri uresničevanju zahtevnega projekta.

Pri projektu, dinamični mreži, sodelujejo vsi, ne da bi bili fizično združeni v kaki drugi že znani obliki strukture organiziranosti. Prednosti strukture organiziranosti v obliki dinamične mreže so v visoki stopnji fleksibilnosti, izrabi človeških virov in večji učinkovitosti ter poslovni uspešnosti. Ta oblika organiziranosti omogoča, da se pri nekem projektu zbere veliko več znanja, kot bi se ga $v$ drugih tipih struktur in to brez dodatnega zaposlovanja.

Posebna oblika mrežne strukture organiziranosti je tudi znana kot virtualna (možna, potencialna, navidezna) organiziranost. Virtualna organiziranost je začasna mreža organizacij, od katerih ima vsaka določene kompetenčne sposobnosti in ki so se združile za izvajanje določene naloge, da bi izrabila nekatere hitro spremenljive položaje v svojem poslovnem okolju. Potrebe po virtualni organiziranosti nastopijo takrat, ko se organizacija sreča s prezahtevno nalogo. Pojav takšne naloge je lahko tudi posledica lastnih raziskav, kjer so odkrite neke možnosti, ki presegajo kompetenčne sposobnosti organizacije in jih organizacija sama ne more izpeljati, ali vsaj ne dovolj kakovostno in ekonomično. Sama organizacija ima lahko pomanjkljive sposobnosti za raziskave in razvoj ali nima dovolj finančnih sredstev, distribucijske mreže itn.

Združitev organizacij je lahko začasna ali trajnejša, odvisno od cilja združevanja. Značilnost združenih organizacij je, da imajo skupno usodo, skupaj razvijajo nov izdelek, skupaj delijo dobiček, med seboj delijo stroške in tehnološke dosežke, dostop na trge, distribucijske kanale idr. Organizacije so medsebojno odvisne druga od druge. Združena organizacija se mora odpovedati delcu svoje prostosti v zameno za skupni uspešni izid.

Zadnja razvojna faza je skupnost e-poslovanja (SEP). Sestavina mreže SEP je "omreženo podjetje/organizacija", ki sodeluje v mreži s svojo ponudbo in povpraševanjem. Temeljna podlaga komuniciranja je sta internet in tehnologija spletnih strani (www). V SEP so znane tri ravni povezovanja (Semolič, 2001, str. 18):

- omreženo podjetje/organizacija,

- skupnost e-poslovanja (SEP) in

- gospodarska panoga.

Prva raven se nanaša na posamezno organizacijo. $V$ drugem primeru gre za določeno skupino sodelujočih organizacij, ki sodelujejo $v$ SEP. Tretja raven pa zajema več SEP, ki medsebojno konkurirajo v okviru določene gospodarske panoge.

Tip SEP organiziranosti ni enoten. Že omernjeni avtor Tapscott razlikuje več različnih tipov SEP glede na ekonomski nadzor (hierarhični ali samoorganizirajoč in integracijo vrednosti (nizka ali visoka) (Semolič, 2001, str. 19). Glede na omenjeni 


\section{Novi trendi v razvoju in organiziranosti sodobnih organizacij}

razsežnosti Tapscott razlikuje nekaj tipov SEP organiziranosti, in sicer ( Semolič, 2001, str. 19):

- združevalec,

- povezovalec,

- vrednostna veriga in

- prostor vrednosti.

SEP združevalec je tip mreže, za katerega je značilno, da je v ospredju organizacija, ki povezuje druga podjetja in organizacije SEP $\vee$ odnosu do kupca.

Slika 1: Zvrsti skupnosti e-poslovanja

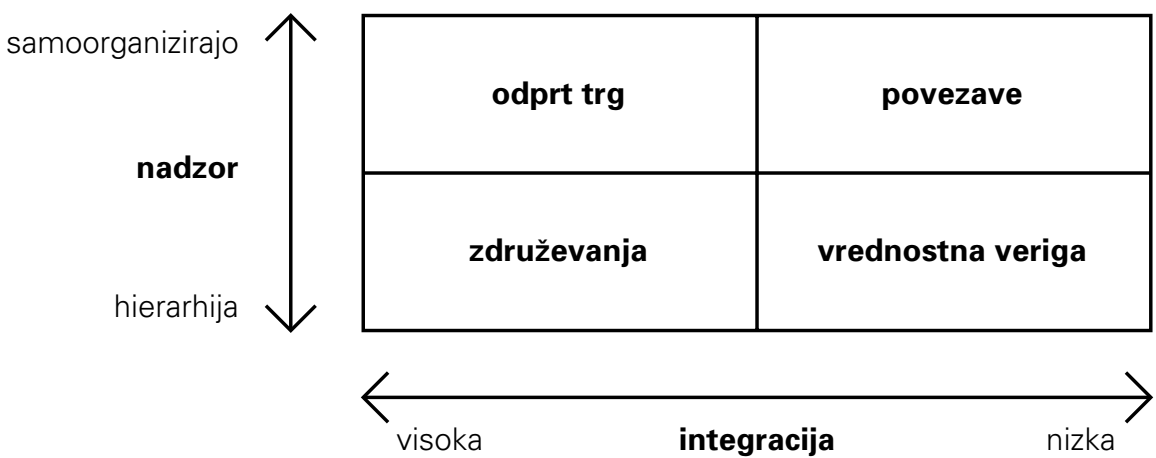

Vir: Prirejeno po Semolič, B.: Projektni management v novi ekonomiji, Projektni Forum ZPM 2001, str. 16.

Tip SEP povezovalec oz. vrednostna veriga je podoben prejšnjemu, vendar je usmerjen $v$ optimiranje poslovnega procesa. Zaradi tega ga tudi obravnavajo pod pojmom SEP vrednostna veriga. Tudi v tem primeru je osrednja vodilna organizacija, ki skuša s svojimi poslovnimi partnerji vzpostaviti optimalno verigo dodane vrednosti.

Za tip SEP zveza je značilno, da deluje brez ekonomskega nadzora. Oblikuje virtualni prostor vrednosti, kjer kupci, ki imajo veliko možnost izbire, sami določajo načine zadovoljevanja svojih potreb.

Izbira tipa povezav organizacije je odvisna predvsem od razvojnih strategij sodelujočih organizacij.

\section{Projektna organiziranost v omrežni organizaciji}

Značilnost sodobnih organizacij je dinamičnost, fleksibilnost in sposobnost hitrega prilagajanja in prepletanja poslovnih procesov operative in razvoja. Da bi te procese lahko organizacijsko uspešno obvladovali, jih moramo najprej dobro poznati. Obstajata dva glavna tipa poslovnih procesov:

- kontinuirani poslovni procesi - ponavljajoči se in

- enkratni poslovni procesi - neponavljajoči se.

Ponavljajoči se poslovni procesi so značilni za serijsko in množično proizvodnjo. Ti procesi se ponavljajo in ostajajo vsebinsko in tudi kakovostno enaki. Posamezni procesi se med seboj razlikujejo le po obsegu proizvodnje določenega že osvojenega izdelka 


\section{Štefan Ivanko}

\section{Novi trendi v razvoju in organiziranosti sodobnih organizacij}

ali storitve. V poslovni mreži sodelujejo organizacije, ki proizvajajo že ustaljene izdelke ali storitve.

Enkratni poslovni procesi, ki imajo značaj projektov, so prisotni v vsaki organizaciji ne glede na to, ali imajo ti poslovni procesi značaj operative ali pa gre za realizacijo razvoja organizacije. $\vee$ neponavljajočih procesih realiziramo enkratne projekte. To pa so $\checkmark$ glavnem inovacije in inovacijski procesi. $\vee$ mrežni organiziranosti se takšni enkratni projekti izvajajo lahko $\vee$ okviru ene organizacije, dveh ali več organizacij ali celotne mreže sodelujočih podjetij.

$\checkmark$ mrežni organiziranosti se tudi funkcije oziroma dejavnosti upravljalnega procesa močno spremenijo. Po Printzu (Semolič, 2001, str. 23) so glavne menedžerske razsežnosti, ki morajo biti prisotne pri menedžmentu vsake organizacije, naslednje:

- operativa,

- razvoj in

- prilagajanje.

Funkcije oziroma dejavnosti menedžmenta, ki so potrebne za obvladovanje posamezne vrste poslovnih procesov, se pri posameznih procesih medsebojno močno razlikujejo. Ena glavnih razlik je $\vee$ tem, da se pri menedžmentu ponavljajočih se procesov, te funkcije nanašajo na vire organizacije, medtem ko so pri projektnem menedžmentu vključeni tudi viri organizacij, ki sodelujejo v poslovni mreži. Pri kontinuiranih procesih so cilji predvsem časovno opredeljeni. Pri menedžmentu procesov pa gre za načrtovanje, organiziranje in nadziranje virov, ki so usmerjeni v uresničevanje enkratnih ciljev, ki jih je treba doseči v natančno določenem roku. Te razlike so očitne. Osnovne značilnosti projektnega menedžmenta glede na menedžment kontinuiranih procesov so po Levinu predvsem tele (Semolič, 2001, str. 24):

- Pri projektnem menedžmentu v mrežni organiziranosti ne gre le za uporabo lastnih virov ene organizacije, temveč večih ali celo vseh v poslovni mreži.

- Menedžment projekta je enkraten proces, ki je časovno točno opredeljen.

- Projektni menedžment je osredotočen na uresničevanje ciljev enkratnega značaja.

- Spremljanje projekta je osredotočeno na količino dela ali del projekta in ne le na časovna obdobja, kot je to značilno pri menedžmentu kontinuiranih procesov.

\section{Zaključek}

Dosežki vrhunske tehnologije vplivajo na spremembe in nastanek globalnih ekonomskih zakonitosti, ki se kažejo $v$ novem globalnem ekonomskem redu, ki ga največkrat imenujemo nova ekonomija. Nova ekonomija nudi nove možnosti organiziranja sodobnih organizacij. Osnovna njena značilnost je, da poslovanje organizacij ni več zaprto $\vee$ okvirje obstoječih organizacij, temveč da se povezujejo z drugimi organizacijami $\vee$ razne oblike poslovnih mrež.

V splošnem velja ugotovitev, da je bila za industrijsko dobo dvajsetega stoletja značilna funkcijska struktura organiziranosti in druge oblike klasične organiziranosti (divizijska, matrična, projektna predvsem znotraj organizacije). V enaindvajsetem stoletju pa se vse bolj uveljavljajo sodobne oblike fleksibilne organiziranost. Ena takšnih je 


\section{Novi trendi v razvoju in organiziranosti sodobnih organizacij}

tudi projektno mrežna organiziranost, ki postaja prevladujoča oblika organiziranja $\vee$ enaindvajsetem stoletju.

Klasične oblike organiziranosti so po svojih značilnostih toge in so usmerjene predvsem $v$ učinkovitost operative in niso primerne za obvladovanje procesov razvoja in prilagajanja.

Fleksibilna projektna - mrežna organiziranost je dinamična mrežna organiziranost, ki je sposobna učinkovitega obvladovanja procesov operative kot tudi projektnih procesov prilagajanja in razvoja.

Pomembna prvina sodobne fleksibilne -projektno usmerjene organiziranosti je tudi kulturno okolje, v katerem organizacije delujejo. Organizacijska kultura organizacij, ki sodelujejo $v$ eni izmed oblik mrežne organiziranosti se ne sme veliko razlikovati od sodelujočih organizacij. Raziskave opozarjajo, da so razlike $v$ uspešnosti in učinkovitosti organizacij odvisne predvsem od dojemljivosti sodelavcev, množice vrednot, predpostavk, zaupanja in motivacije sodelavcev, ki sodelujejo $v$ eni od oblik mrežne organiziranosti. Učinkovitost in uspešnost sodobnih organizacij je v precejšnji meri odvisna od skladnosti med organizacijsko kulturo, strategijo, organiziranostjo in menedžmentom organizacije.

Nova ekonomija oziroma spremenjene razmere dela in poslovanja, ki jih spremlja hiter tehnološki razvoj, predvsem v informacijski in telekomunikacijski tehnologiji, terja visoko stopnjo razvojne sposobnosti in prilagodljivosti vseh organizacij. Nove razmere dela in poslovanja, v katere vse hitreje vstopamo, terjajo od organizacij prenove poslovanja. Nova organiziranost bo morala zagotoviti uspešno notranje obvladovanje ključnih sestavin in oblikovati ter obvladovati poslovne mreže, prek katerih si bodo organizacije zagotavljale potrebno zunanje vire, potrebne za izvajanje svojih dejavnosti.

\section{Literatura in viri}

1. Drucker, Peter: Post - capitalist Society. Oxford: Butterwoorth - Heinemann, 1993.

2. Ivanko Š.: Strukture in procesi v organizaciji, Visoka upravna šola, Ljubljana 2002.

3. Sundać, D.: Prilozi za novu ekonomsko znanost,, Verzal, Rijeka 1992.

4. Samuelson, P.: Ekonomija, Mate, Zagreb 1992.

5. Semolič, Brane et al: Projektni management v novi ekonomiji, Forum ZPM 2001, Slovensko združenje za projektni management, Maribor 2001.

6. Tapscott, Don: Blueprint to the Digital Economy, McGraw Hill, New York 1998.

7. Uzelac, J.: Kibernetizacija poslovnog sustava, Benja, Rijeka 1994.

8. Vila A.: Nova organizacijska revolucija, Organizacija št. 6, Kranj 1998.

9. Zekić, Zdravko: Logistički menedžment, Glosa, Rijeka 2000.

Štefan Ivanko je redni profesor na Fakulteti za upravo v Ljubljani. V svojem pedagoškem in raziskovalnem delu se ukvarja s teorijo organizacije, projektiranjem organizacijskih sistemov in menedžmentom. Pri svojem dolgoletnem pedagoškem in raziskovalnem delu je objavil preko 200 pomembnih del s področja organizacije in menedžmenta; od tega 14 samostojnih knjig. 
Štefan Ivanko

Novi trendi v razvoju in organiziranosti sodobnih organizacij

\section{SUMMARY \\ New Trends in Development and Organising of Contemporary Organisation}

This contribution illuminates the trends in development, management and organizing of contemporary organizations, which show themselves especially in dissuasion of output from the sources of raw materials and employment, globalization of organizing, in modification of aims and ways of functioning. The sources of transformation and efficiency of management of contemporary organizations are shown integrated like informations, comunications, knowledge and management, which are becoming the basic factors of efficient management of contemporary organizations. The modified factors of efficiency of management also claim modifications in organizing of contemporary organizations. The forms of contemporary organizing are first of all forms of net and virtual organizing and communities of e-management. Project organizing occupies a special place in net organizing and becomes an important composition of management to each contemporary organization.

The acchievements of top technology affect the modifications and the origin of global economic legalities which are shown in the new economic order that we often name the new economy. The new economy ofers new possibilities of organizing of contemporary organizations. Its basic feature is that the management of organizations is no longer closed into the frames of exisisting organizations but is connecting with other organizations into different forms of management networks.

As a rule the statement that functional structure of organizing and other forms of classic organizing (divisional, matrix and projects mainly within the organization), are features of the industrial era of the twentieth century, is valid. In the 21 st century modern forms of flexible organizing are more and more coming into force. One of them is also the projective net organizing which becomes a dominant form of organizing in the 21 st century.

The classic forms of organizing are, based on their features, rigid and mainly focused on the efficiency of the operative and are not suitable for dominating the process of development and adjustment.

The flexible projective net organizing is dinamic net organizing which is capable of efficient dominating of operative process as also the adjustment and development process.

An important element of contemporary flexible - project directed organization is also the cultural background in which the organizations function. The organizing culture of the organizations which participate in one of the forms of net organizing shall not differ much from other participating organizations. Researches notice that differences in efficiency and effectivness largely depend on the comprehension of the co-workers, the mass of values, presumes, trust and motivation of the co-workers which participate in one of the forms of net 
organizing. The effectivness and efficiecy of contemporary organizations in considerable extent depends on the harmony between the organizing culture, strategy, organizing and the management of the organization.

The new economy, respectively the modified conditions of work and management which are accoompanied with the technological development especially in the information and telecomunications technology, claims a high degree of development capability and adaption of all organizations. The new work and management conditions in which we enter faster and faster, claim an innovation of management from the organizations. The new organizing will have to assure an effective inner control of key compositions and be able to form and control the management networks in which the organizations assure their neccesary external sources, neccesary for performing their own actions. 